\title{
Upaya Peningkatan Utilitas Bengkel Disabilitas pada Komponen Motor Roda Tiga dengan E-commerce
}

\author{
Sugiono $^{1}$, Bayu Rahayudi ${ }^{2}$, Rudianto Raharjo ${ }^{3}$, Dwi H. Sulistyarini ${ }^{4}$ \\ Universitas Brawijaya, Jl. Veteran, Ketawanggede, Kec. Lowokwaru, Kota Malang, Jawa Timur \\ 65145 \\ Email: sugiono_ub@ub.ac.id ${ }^{1}$
}

\begin{abstract}
ABSTRAK
Peranan disabilitas dalam membangun ekonomi tidak bisa dikesampingkan begitu saja karena jumlah yang cukup banyak dan keahlian yang dimiliki. Paper ini bertujuan untuk meningkatkan keuntungan bengkel difabel dengan mengoptimalkan utilitas mesin yang ada melalui penjualan e-commerce. Langkah pertama yang dilakukan adalah studi literature tentang utilitas mesin, e-commerce, dan ekonomi teknik. Kemudian dilanjutkan dengan menghitung utilitas existing pada mesin bengkel sebesar 50\%. Penjualan dengan ecommerce mampu dapat mendongkrak penjulan yang sebelumnya terdapat order 2 motor per bulan menjadi 3 motor perbulan. Selain itu juga terjadi penambahan order terhadap komponen motor seperti roda gigi, sumbu, dll yang cukup banyak. Sehingga mampu menaikkan utilitas bengkel secara signifikan melalui ecommerce dengan besaran sebesar $100 \%$. Secara singkat dapat dikatakan bahwa instalasi e-commerce dapat menaikkan nilai utilitas bengkel dengan baik.
\end{abstract}

Kata kunci: Motorcycle Repair; Utilitas Mesin; E-commerce; Disabilitas

\section{ABSTRACT}

The role of disabilities in developing the economy cannot be ignored because of the large number of people and their skills. This paper aims to increase the profitability of disabled workshops by optimizing existing machines' utility through e-commerce sales. The first step taken is a literature study on machine utility, ecommerce, and engineering economics. Then proceed by calculating the utility of the existing machine workshop by 50\%. E-commerce sales can boost sales from previously ordered 2 motorbikes per month to 3 motorbikes per month. Besides, there were also quite many orders for motor components such as gears, axles, etc. To significantly increase the utility of the workshop through commerce with an amount of $100 \%$. In short, it can be said that e-commerce installation can increase the utility value of a workshop well.

Keywords: Motorcycle Repair; Machine Utilities; E-commerce; Disabilities

\section{PENDAHULUAN}

Disable people merupakan orang yang memiliki kekurangan pada fisik dan atau mental, sehingga dapat mengganggu dan menghambat dirinya untuk melakukan kegiatannya sehari-hari dalam hidup yang wajar. Liisberg (2017) dalam bukunya menyatakan bahwa pada artikel 27 United Nations mengatur secara detail tentang disabilitas dan kesempatan kerja. Menurut International Labour Organisation (ILO) orang penyandang disabilitas diperkirakan berjumlah satu miliar, atau 15 persen, dari total 
populasi dunia. Sekitar 80 persen adalah usia produktif kerja. Namun, hak para penyandang disabilitas atas pekerjaan yang layak sering masih sering mendapatkan hambatan (ILO, 2015) yang berupa hambatan sikap, fisik, dan informasi terhadap kesempatan yang sama di dunia kerja. Para disabilitas juga memiliki hak yang sama dengan pekerja lain yang tertuang dalam Konstitusi Republik Indonesia Pasal 28D ayat (2) yang menyatakan bahwa setiap orang memiliki hak untuk bekerja dan untuk mendapatkan kompensasi dan perawatan yang adil dan layak. dalam hubungan kerja. Jadi para disabilitas juga memiliki hak untuk bekerja tanpa diskriminasi. Pemerintah juga memiliki kewajiban untuk memenuhi hak-hak para penyandang disabilitas khususnya untuk mendapatkan pekerjaan. Undang-Undang Nomor 8 Tahun 2016 tentang Penyandang Disabilitas Pasal 11 huruf (g) menyatakan memiliki peluang untuk mengembangkan jalur karier dan semua hak normatif yang melekat di dalamnya. Perusahaan swasta dan BUMN harus mempekerjakan setidaknya $1 \%$ penyandang disabilitas dan perusahaan yang mempekerjakan penyandang disabilitas diatur dalam Undang-Undang No. 13 tahun 2003 tentang Ketenagakerjaan. Pasal 67 ayat (1) menyatakan bahwa pengusaha yang mempekerjakan pekerja penyandang disabilitas harus memberikan perlindungan sesuai dengan jenis kedisabilitasanya.

Pentingnya menghitung produktivitas adalah untuk mengetahui tingkat output dari suatu input dalam proses produksi. Dengan mengetahui produktivitas maka manajemen perusahaan dapat merencanakan faktor-faktor produksi yang dibutuhkan dalam proses produksi, demikian juga dapat merencanakan jumlah. Produktivitas biasanya didefinisikan sebagai rasio antara volume output dan volume input (Rüßmann, 2015). Produktivitas akan mengukur seberapa efisien input produksi, seperti tenaga kerja dan modal, digunakan dalam perekonomian menghasilkan tingkat output tertentu. Produktivitas dianggap sebagai sumber utama pertumbuhan ekonomi dan daya saing bangsa. Tangen (2002) menyatakan bahwa secara umum produktivitas dalam rekayasa industri didefinisikan sebagai hubungan antara output (yaitu barang yang diproduksi) dengan input (yaitu sumber daya yang dikonsumsi) dalam transformasi proses manufaktur. Oleh karena itu, produktivitas sangat erat hubunganya dengan penggunaan dan ketersediaan sumber daya. Bisa dikatakan bahwa produktivitas akan berkurang jika sumber daya perusahaan tidak digunakan dengan benar. Tujuan utama dari pengukuran produktivitas berkaitan dengan teknologi, efisiensi, real cost saving, benchmarking proses produksi, dan standart hidup (Oecd, 2001).

Rüßmann (2015) menyatajan bahwa industri 4.0 akan mengubah desain, manufaktur, operasi, dan layanan produk dan sistem produksi. Konektivitas dan interaksi antara bagian- 
bagian, mesin, dan manusia akan membuat sistem produksi sebanyak 30 persen lebih cepat dan 25 persen lebih efisien dan meningkatkan kustomisasi massal ke tingkat baru. Vaidya dkk. (2018) memberikanlaporan bahwa digitalisasi dan kecerdasan proses manufaktur adalah kebutuhan untuk industri saat ini. Industri manufaktur saat ini berubah dari produksi massal ke produksi khusus. Kemajuan pesat dalam teknologi manufaktur dan aplikasi dalam industri membantu dalam meningkatkan produktivitas. Industri 4.0 akan sangat membutuhkan keberadaan akan Internet of Things, Internet Industri, Smart Manufacturing, dan Cloud Manufacturing (Chang, 2014; Lu, 2017; Kaur dkk., 2018). Industri 4.0 memperhatikan integrasi manusia yang ketat dalam proses manufaktur sehingga memiliki perbaikan terus-menerus dan fokus pada kegiatan bernilai tambah dan menghindari pemborosan (Kinzel, 2016). Salah satu caranya adalah memanfaatkan perkembangan teknologi di era industri 4.0 yang mengubah cara kerja dilakukan dari cara konvensional menuju teknologi digital dengan memanfaatkan e-commerce. Dengan adanya e-commerce akan membantu menigkatkan permintaan, sehingga produksi akan menjadi lebih besar dan utilitas dari mesin menjadi meningkat. Hal inilah yang medasari salah satu bengkel disabilitas untuk dapat menerapkan e-commerce dalam penjualan produksi komponen sepeda motor roda tiga.

\section{METODE}

E-commerce menciptakan industri yang gesit yang memiliki data pelanggan, kebiasaan pelanggan, dan trend industri yang berkembang. Menggunakan kemampuan pencarian online, pelanggan dari penjuru dunia dapat menemukan dan membeli produk yang diinginkan. Seringkali, menjalankan bisnis e-commerce tidak perlu duduk di kantor terus, laptop dan koneksi internet yang baik adalah semua yang diperlukan untuk mengelola bisnis dari mana saja di dunia. Ada urutan logis bagaimana membangun toko online e-commerce. Meskipun mendirikan toko online yang sebenarnya mungkin akan memakan waktu kurang dari sehari, meneliti, membangun, meluncurkan dan menumbuhkan bisnis e-commerce yang menguntungkan adalah proses bertahapyang melibatkan sejumlah langkah dan keputusan. Adapun tahapan dalam menjalankan ecommerce diantaranya yaitu: memilih dan mencari produk, melakukan penelitian dan perencanaan ke depan, memperbaiki merek produk, dan memutuskan bagaimana akan menjual. Interface minimal yang harus ada dalam e-commerce adalah: features, ease of use, pricing, templates \& design, inventory, SEO \& Marketing, payments, security, and customer support. 
Kegiatan ini bertujuan untuk meningkatkan utilitas penggunaan mesin pada bengkel difabel untuk pembuatan motor roda tiga dan komponenya. Desain penelitian yang digunakan berupa studi kasus yaitu kasus yang sedang dihadapi bengkel saat ini. Sedangkan metode pembahasan menggunakan metode deskriptif yaitu membuat gambaran atau deskripsi secara sistematis, faktual, dan akurat mengenai performansi bengkel difabel yang diteliti. Jenis data yang digunakan adalah data sekunder yang meliputi data mengenai urutan proses produksi, foto-foto mesin produksi, data jumlah produksi, jam kerja normal per minggu, dan minggu kerja per semester. Sedangkan data primer berupa waktu yang dibutuhkan untuk pembuatan produk. Gambar 1, menunjukkan langkah yang dilakukan dalam mengerjakan riset diantaranya yaitu: survei kebutuhan produk motor roda tiga, pembuatan produk, control kualitas, instalasi ecommerce, analisis dan pembahasan. Jika penjualan tidak meningkat maka langkah yang dilakukan adalah evaluasi produk baik berupa jenis maupun kualitasnya.

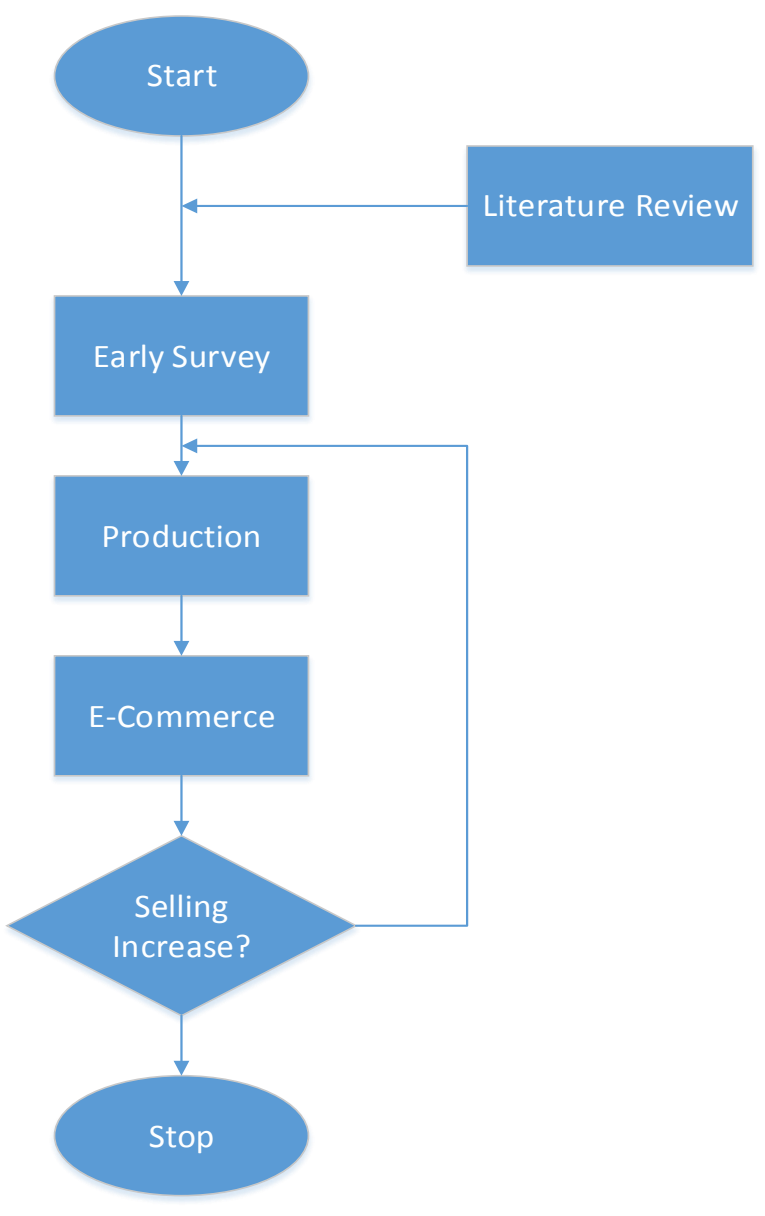

Gambar 1. Flowchart e-commerce bengkel disabilitas 


\section{HASIL, PEMBAHASAN, DAN DAMPAK}

Pembuatan motor roda tiga untuk disabilitas adalah unik dan memerlukan beberapa komponen modifikasi seperti: roda, poros, rem dan lainya. Peralatan utama bengkel yang dibutuhkan diantaranya yaitu mesin bubut, mesin drilling, gerinda, mesin las dan lainya. Teknik dan tahapan dalam pengerjaan permesinan mengikuti prosedur secara professional. Tahapan permesinan secara umum dibagi menjadi empat tahap yaitu desain, persiapan material bahan baku, proses permesinan, dan finishing. Pada tahap desain dilakukan berdasarkan kebutuhan ukuran dari motor yang akan dimodifikasi. Untuk komponen utama desain dan ukuranya adalah tetap mengacu pada kebutuhan teknis.
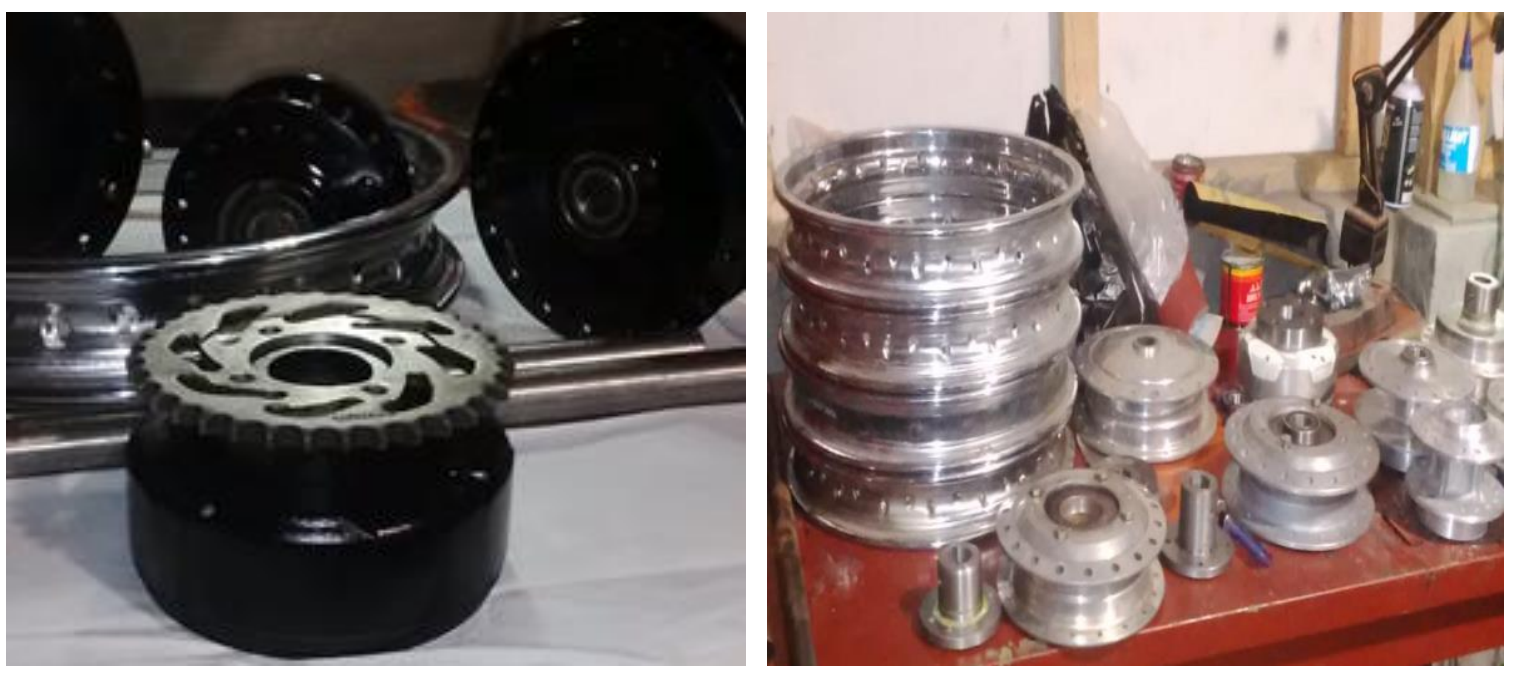

Gambar 2. Persiapan produk untuk stok dalam rangka e-commerce

Untuk menghitung utilitas mesin pada bengkel maka dibutuhkan informasi terhadap jumlah produksi, waktu tersedia, dan waktu siklus pembuatan. Menggunakan persamaan perhitungan nilai performance rate. Performance Rate merupakan ratio yang menunjukan kemampuan peralatan dalam menghasilkan produk. Data yang digunakan untuk pengukuran performance rate adalah output, ideal time actual dan operating time (Ansori, 2013). Sebelum menerapkan e-commerce jumlah produk yang dihasilkan dalam waktu satu bulan adalah 2 motor dengan waktu penyelesaian 2 minggu per motor. Sehingga dapat dikatakan bahwa performansi dari bengkel pada waktu itu adalah:

Performance $=($ jumlah produk yang dihasilkan / total waktu yang tersedia $\mathrm{x}$ cycle time $) \mathrm{x}$ $100 \%$

$=(2$ unit $/ 4$ minggu $) \times 1$ minggu

$=50 \%$ 
Setelah menerapkan e-commerce terjadi peningkatan 2 kali lebih banyak daripada sebelumnya, dimana terjadi 4 motor pemesanan dalam waktu satu bulan. Kondisi seperti ini secara normal sudah cukup maksimal, dimana tidak ada lagi kesanggupan untuk memproduksi order motor modifikasi. Namun demikian pihak bengkel bisa meningkatkan performance lagi dengan memproduksi komponen motor (poros, roda gigi, cakram, dll) modifikasi roda tiga untuk disabilitas atau dengan menambah tenaga kerja. Berikut adalah performasi secara sederhana pemanfaatan mesin di bengkel disabilitas:

Performance $=($ jumlah produk yang dihasilkan / total waktu yang tersedia $\mathrm{x}$ cycle time $) \mathrm{x}$ $100 \%$

$$
\begin{aligned}
& =(4 \text { unit } / 4 \text { minggu }) \times 1 \text { minggu } \\
& =100 \%
\end{aligned}
$$

\section{SIMPULAN}

Penerapan e-commerce pada bengkel motor modifikasi roda tiga yang diakukan oleh disabilitas mampu memberikan keuntungan (i) E-commerce memaksa manajemen bengkel untuk bekerja lebih baik dan terukur, dikarenakan harus menyiapkan stok komponen motor sehingga akan memperbaiki kinerja marketing. (ii) Secara langsung dengan menerapkan ecommerce akan memberikan promosi yang luar biasa pada jaman serba digital. (iii) Dengan meningkatnya order pada bengkel, maka akan menaikan nilai performansi bengkel secara signifikan yaitu dari $50 \%$ menjadi $100 \%$.

\section{UCAPAN TERIMAKASIH}

Penghargaan kami sampaikan kepada Universitas Brawijaya, Indonesia yang telah mendukung pengabdian pada masyarakat ini. Pelaku juga mengucapkan terimakasih kepada kelompok peneliti Bioengineering, Laboratorium Perancangan Kerja dan Ergonomi Jurusan Teknik Industri Universitas Brawijaya, Malang, Indonesia atas dukunganya yang luar biasa.

\section{DAFTAR PUSTAKA}

Ansori, N. (2013). Sistem Perawatan Terpadu (Integrated Maintenance System). Graha Ilmu, Yogyakarta

Chang, K. H. (2014). Bluetooth: A viable solution for IoT? [Industri Perspectives]. IEEE Wireless Communications. https://doi.org/10.1109/MWC.2014.7000963 
Kaur, G., Tomar, P., \& Singh, P. (2018). Internet of Things and Big Data Analytics Toward Next-Generation Intelligence. In Springer International Publishing AG 2018. https://doi.org/10.1007/978-3-319-60435-0

Kinzel, H. (2016). Industri 4.0 - Where does this leave the Human Factor? 27th Annual Conference of Human Dignity and Humiliation Studies.

Liisberg, M. V. (2017). Article 27 [Work and employment]. In The United Nations Convention on the Rights of Persons with Disabilities: A Commentary. https://doi.org/10.1007/978-3-319-43790-3_31

Lu, Y. (2017). Journal of Industrial Information Integration Industri 4. 0: A survey on technologies, applications and open research issues. Journal of Industrial Information Integration. https://doi.org/10.1016/j.jii.2017.04.005

Oecd. (2001). Overview of productivity measures. Measuring Productivity - OECD Manual. https://doi.org/10.1787/9789264194519-en

Rüßmann, M. dkk. (2015). Future of Productivity and Growth in Manufacturing. Boston Consulting. https://doi.org/10.1007/s12599-014-0334-4

Tangen, S. (2005). Demystifying productivity and performance. International Journal of Productivity and Performance Management. https://doi.org/10.1108/17410400510571437

Vaidya, S., Ambad, P., \& Bhosle, S. (2018). Industri 4.0 - A Glimpse. Procedia Manufacturing. https://doi.org/10.1016/j.promfg.2018.02.034

Zulkarnain Ridwan, â€^Perlindungan Hak-Hak Konstitusional Penyandang Disabilitas (Rights of Persons With Disabilities) (2013) 7 Fiat Justisia Jurnal Ilmu Hukum. 